\title{
People, organizational culture and change - also known as e-learning fundamentals
}

\author{
Melanie Sutton \\ Independent Information Management Specialist \\ msutton@i-innovate.co.za
}

\section{Introduction}

The new knowledge economy demands that organizations continually convey information to employees and clients, tap into employees' intellectual capital, assemble and provide access to this tacit information and develop best practices and collective learning. At the same time, organizations must reduce the costs involved in creating this workforce that performs better and faster than the competition (Brockbank 2002). Bring on e-learning, shout the masses!

E-learning is diverse and goes beyond courseware and instruction, to generating and disseminating information and directly supporting organizational performance. It provides access to information that represents the collective wisdom of an organization (Rosenberg 2001).

However, the success of an e-learning strategy depends largely on the people using it to gain knowledge and skills. This is especially true for enterprise-wide solutions that represent a significant change in work processes and the role of learning within an organization. It is also a well-known fact that the majority of people resist change, regardless of its benefits (Geisman 2001).

Organizational e-learning strategies have traditionally focused on technical and implementation issues. Yet people remain the most influential element of any technology undertaking. While technical infrastructures can always be upgraded or replaced, altering human perceptions and attitudes requires almost divine intervention. People, organizational culture and change are fundamentally what e-learning is all about.

\section{E-learning is a useful strategy to have}

Successful e-learning strategies help organizations develop and maintain a competitive advantage in attracting and hiring new employees and retaining the intellectual (human) capital. It is also beneficial in succession planning where peak performers are identified and developed according to appropriate competencies (Brockbank 2002)

E-learning also has several advantages that directly impact the bottom line, including:

- Lowering the cost of training by reducing training overheads and travelling costs, thereby increasing the number of potential learners in a geographically dispersed workplace (Brown 2002).

- Reduces down-time for regular business initiatives - online learning solves one of the big obstacles to training which is getting time away from the office.

- Provides the means for a self-paced and private learning environment (Steinbrecher 
2003).

- Provides a mechanism for a consistent interface while being fully integrated with other enterprise systems, while the number of employees accessing the information does not sacrifice lesson quality.

- E-learning supports the need for 'Just In Time' information. Web-based training modules assist in boosting retention and making information accessible. Employees can learn about new policies, read about software upgrades, and find answers to questions online (Bannan 2003).

\section{People, organizational culture and change can be obstacles to e-learning success}

Cloete, Van der Merwe and Pretorius (2003) place e-learning failures into two categories, namely (a) technological and interoperability complexities, and (b) dissatisfaction, concern, agitation and lack of commitment from the stakeholders. Furthermore, an inadequate understanding of the organizational structure, processes and culture of the application domain will probably eventuate in the non-acceptance of e-learning integration into the working environment (Cloete, Van der Merwe and Pretorius 2003) .

E-learning failures are more often the result of organizations failing to provide necessary support for employees who may now have new roles and who require new skill sets and competencies to perform in the workplace (Sevilla and Wells 2002).

Numerous organizational cultural issues can affect e-learning adoption in organizations. In a recent poll, Forrester Research ranked cultural resistance as a major obstacle to successful elearning success (41\%). Geisman (2001) claims that the four most significant cultural issues include the accepted use of computers for job tasks only, failure to ask questions about the bottom-line impact of a shorter learning curve or the ways in which increased accuracy and improved quality can affect revenues, and an unwillingness to invest in new technology especially for training-related activities and the belief that training is an expense rather than an investment.

\section{How can we build successful e-learning strategies?}

\subsection{Planning}

An effective e-learning strategy must be more than technology or the content it carries. It must also focus on critical success factors that include building a learning culture, marshalling true leadership support, deploying a nurturing business model and sustaining the change throughout the organization (Rosenberg 2001).

The strategy must also address issues such as the technological literacy level of employees, existing job descriptions, the organizational culture, e-learning technology requirements and governance over the e-learning process (Grant and Danzinger 2003).

Planning and executing a successful e-learning strategy involves organizational and individual needs assessment, skills gap analysis, goal setting, and curriculum design based on the previously identified needs (Weggen 2002). Organizations must design learning materials that will assist in filling these skill gaps and the appropriate method for delivering learning should be based on the learning needs of an organization's employees, not simply as a means to cut costs (Coleman and LaPlace 2002).

\subsection{Communicating change}

One of the most important actions you can take in managing change and championing e- 
learning is to communicate effectively. Effective communication will help to gain understanding and acceptance of an e-learning program. The communication strategy should consider the following questions (Broadbent 2003):

- Which groups need to know about the e-learning program?

- Which messages does each group need to hear?

- What should each group not hear?

- When should the messages be sent?

- How should the messages be distributed?

- Who should be the spokesperson for the messages?

- Who should not deliver the messages?

- Where do you require assistance to deliver the messages?

- Who can help where you require assistance to deliver the messages?

- How should you approach people who can help you?

When communicating change, it is important that messages are consistent with actions and that the e-learning strategy is continuously promoted, to maintain interest and awareness. An effective strategy also anticipates organization and learner resistance and addresses this resistance.

\subsection{Leading the way}

E-Learning strategies require leaders and/or managers to become partners in an employee's learning experience, assisting an employee to adjust to the integration of work and learning. A hybrid of e-learning and peer-to-peer interaction is a valuable approach, providing important feedback and support for the learner. Rewards and recognition need to be set in place to ensure that the experts are willing to participate in coaching learners. The Chief Learning Officer (www.clomagazine.com) online magazine offers some useful tips on leading in an e-learning environment.

\subsection{Make learners take responsibility for learning}

The single most defining element in an e-learning implementation is the self-discipline required of a learner to find the time and interest to self educate (Steinbrecher 2003). It is vital that learners take responsibility for their e-learning experience, but that expectation must be communicated to them both by management and by the facilitator and must be inherent in the learning content (Sevilla and Wells 2002). Because the nature of e-learning is in principle self-paced learners will need motivation and personal tenacity to succeed. Usually, learners will be expected to organize their own training schedules, choosing when and how they navigate through modules (Sweeney 2001).

To assist learners to succeed in their learning journey, they should be encouraged to allocate time to commit to a training schedule, discuss their learning commitment with their manager and co-workers. Taking responsibility for learning implies that learners will be considerate of other employees, set realistic learning goals and be an active participant in the experience. Learners should create peer e-learning groups to maximize their learning and increase their retention rates. Learners should apply their newly acquired knowledge and skills in their work situations and make use of all available resources to maintain their learning experience.

Further information on e-learning strategies and motivating learners can be found at www.learningcircuits.org, the online e-learning magazine published by the American Society for Training and Development (ASTD). A free source of information about e-learning is www.e-learningcentre.co.uk, which offers practical advice on how to prepare for an elearning implementation (www.e-learning.co.uk/eclipse/Resources/default-preparing.htm), 
while www.e-learningmag.com and www.e-learningguru.com are further sources of useful information, templates, white papers and links on e-learning topics.

\section{Case Studies}

The following organizations implemented successful e-learning strategies that delivered measurable results.

\begin{tabular}{|l|l|}
\hline Deloitte Consulting & Management consulting company \\
\hline Background & $\begin{array}{l}\text { This consulting firm recognized a need to improve } \\
\text { business technology acumen in order to take } \\
\text { advantage of the burgeoning field of e-business. }\end{array}$ \\
\hline Objective & $\begin{array}{l}\text { Get } 15000 \text { employees certified in an internally } \\
\text { developed e-business curriculum. }\end{array}$ \\
\hline E-learning strategy & $\begin{array}{l}\text { Create a training programme based largely on e- } \\
\text { learning content, sweetened with incentives for } \\
\text { successful completion. Provide employees with 'just } \\
\text { in time’ information }\end{array}$ \\
\hline Result & $\begin{array}{l}\text { The project was completed in 9 months. E-learning } \\
\text { initiative overhauled the consulting firm's training } \\
\text { function. Duplicate, under-used courses were } \\
\text { eliminated, classroombased learning was transformed } \\
\text { into blended solutions of Web delivered courses and } \\
\text { traditional training. } \\
\text { Blended solutions, online courses, guidance and } \\
\text { advice through online collaboration, synchronous } \\
\text { learning, seminars, chats, bulletin boards, online } \\
\text { learning management to guide learners in } \\
\text { determining skills and learning they need. } \\
\text { Training costs were cut by more than half. In 1999, } \\
\text { the company spent US\$7500 per employee on } \\
\text { training, in 2002, the costs dropped to US\$3000 per } \\
\text { employee (Gold 2003). }\end{array}$ \\
\hline
\end{tabular}

\begin{tabular}{|l|l|}
\hline J.C. Penney Co. Inc & $\begin{array}{l}\text { One of America's largest department store, } \\
\text { drugstore, catalogue and e-commerce retailers, } \\
\text { employing approximately 249000 associates, with } \\
\text { operations in the United States, Puerto Rico, } \\
\text { Mexico and Brazil. }\end{array}$ \\
\hline Background & $\begin{array}{l}\text { Biggest training challenge was geography and costs } \\
\text { were prohibitive, meaning that only 10\% of the J.C. } \\
\text { Penney population were able to be trained per year }\end{array}$ \\
\hline Objective & $\begin{array}{l}\text { Provide a consistent training programme that would } \\
\text { meet everyone’s needs and the needs of the business. }\end{array}$ \\
\hline E-learning strategy & $\begin{array}{l}\text { Embraced a distance learning model, using integrated } \\
\text { technologies with training programmes lasting no } \\
\text { longer than two hours and students get live, } \\
\text { interactive training that includes pre-test and post- } \\
\text { class testing. } \\
\text { Also provides communities of practice that are }\end{array}$ \\
\hline
\end{tabular}




\begin{tabular}{|l|l|} 
& $\begin{array}{l}\text { accessible from any desktop in any J.C. Penney store. } \\
\text { Provides ability to interact and receive guidance from } \\
\text { peers and subject matter experts. New employees are } \\
\text { given self-study training and puts them in touch with } \\
\text { peers and subject matter experts. }\end{array}$ \\
\hline Result & $\begin{array}{l}\text { Implemented in 1996, the company has saved US\$1 } \\
\text { million every year due to reduced travel costs, } \\
\text { printing, warehousing and mailing training } \\
\text { programmes. } \\
\text { Ability for the company to train more employees, } \\
\text { more consistently (Hollis 2003). }\end{array}$ \\
\hline
\end{tabular}

\begin{tabular}{|l|l|}
\hline Toys 'R' Us Inc & $\begin{array}{l}\text { Chain of toy stores and other retail properties } \\
\text { including Kids 'R' Us, Babies 'R' Us, the } \\
\text { Imaginarium and toysrus.com. }\end{array}$ \\
\hline Background & $\begin{array}{l}\text { Company strategy was to create associates and } \\
\text { leaders in their stores dedicated to delighting guests - } \\
\text { these skills have to be trained, learned and reinforced. }\end{array}$ \\
\hline Objective & $\begin{array}{l}\text { To yield benefits to their customers by creating the } \\
\text { best-trained, most guest-oriented service providers. } \\
\text { To provide employees with the right skills at the right } \\
\text { time in their careers. To support their business } \\
\text { strategy with skills, values and knowledge that will } \\
\text { change the business positively and to provide } \\
\text { stockholders with the best return on training } \\
\text { investment. }\end{array}$ \\
\hline E-learning strategy & $\begin{array}{l}\text { Set up a blended learning solution that includes } \\
\text { directed activities in stores, self-based training, } \\
\text { instructor-led and Web-enabled solutions. }\end{array}$ \\
\hline Result & $\begin{array}{l}\text { Training is valued as a business partner and not a } \\
\text { support group. Learning is utilized strategically and } \\
\text { is perceived as transformational. } \\
\text { Developed a training process that is planned, focused } \\
\text { and aligned to help drive the business goals. } \\
\text { Created a learning culture with shared, measured } \\
\text { accountability throughout the organization (Sosbe } \\
\text { 2003). }\end{array}$ \\
\hline
\end{tabular}

\begin{tabular}{|l|l|}
\hline Steelcase & $\begin{array}{l}\text { Ranked number 425 on the Fortune 500 list, } \\
\text { Steelcase is a leader in the global office furniture } \\
\text { industry. }\end{array}$ \\
\hline Background & $\begin{array}{l}\text { Company wide migration from SAP version } 3.1 \text { to } \\
\text { version 4.6. Requirement to up-skill } 2000 \text { employees. } \\
\text { Previous training included paper-based courseware } \\
\text { material and instructor-led PowerPoint presentations. } \\
\text { This methodology was ineffective once employees } \\
\text { were back at their desks trying to use the system. } \\
\text { Users needed hands-on use of the system. In addition, }\end{array}$ \\
\hline
\end{tabular}




\begin{tabular}{|c|c|}
\hline & $\begin{array}{l}\text { it was resource intensive, time consuming, had high } \\
\text { overheads in producing and maintaining the written } \\
\text { materials. It was expensive because building and } \\
\text { maintaining the courses required a full-time staff of } \\
20 \text { with significant costs for printing and production } \\
\text { costs. }\end{array}$ \\
\hline Objective & $\begin{array}{l}\text { To make learning more effective, giving employees } \\
\text { opportunity to use a simulated system to bolster } \\
\text { retention and understanding of course material, keep } \\
\text { costs down and reduce the burden on course } \\
\text { developers, subject matter experts and course } \\
\text { participants. }\end{array}$ \\
\hline E-Learning Strategy & $\begin{array}{l}\text { Used Web-based authorware to create 'living' } \\
\text { courses that incorporated a series of SAP simulations, } \\
\text { coupled with instructional and mentoring benefits } \\
\text { associated with traditional instructor-led courses. }\end{array}$ \\
\hline Result & $\begin{array}{l}\text { Created } 70 \text { SAP training courses in } 60 \text { days, reduced } \\
\text { the length of each course by } 50 \% \text { and made it } \\
\text { possible to migrate } 2000 \text { SAP users to new upgraded } \\
\text { system in record time. Eliminated need for dedicated } \\
\text { SAP system for training, saved US } \$ 30000 \text { on printed } \\
\text { courseware materials annually, reduced courseware } \\
\text { development staff, reduced the volume of calls to the } \\
\text { SAP technical support help desk. User retention } \\
\text { increased (Bruce } 2002) \text {. }\end{array}$ \\
\hline
\end{tabular}

Further case studies on e-learning implementation can be found at www.clomedia.com/casestudies/

\section{Conclusion}

An e-learning strategy that recognizes the importance of the people, organizational culture and change in its implementation has the capacity to generate improvements in productivity, knowledge retention and application, effective talent deployment, individual and workplace dynamics, critical attitudes and behaviours and job depth and dimension.

Once the human and organizational condition has been addressed, the appropriate learning environment can be developed to support it. Only then will on-demand, anytime/anywhere elearning become a powerful complement to existing development efforts for organizations.

\section{References}

Bannan, K. 2003. Recipe for success. [Online]. Available WWW: www.destinationcrm.com/articles/ default.asp?ArticleID=2768

Broadbent, B. 2003. Facing resistance to change: the dark side to your e-learning project. [Online]. Available WWW: www.e-learninghub.com/articles/dark-side.html

Brockbank, J. 2002. A crash course on e-learning portals. [Online.]. Available WWW: wirelessnewsfactor.com/perl/story/15804.html

Brown, A.S. 2002. Training on a budget - online courses bring learning to newspapers. [Online]. Available WWW www.naa.org/presstime/PTSection.cfm?SID=547 
Bruce, M. 2002. Steelcase: migrating employees to new systems. [Online]. Available WWW: http://www.clomedia.com/content/templates/clo_casestudies.asp?articleid=29\&zoneid=10

Cloete, E., Van der Merwe, A.J., Pretorius, L. 2003. E-learning in a strategic educational institution. [Online]. Available WWW: http://osprey.unisa.ac.za/TechnicalReports/ TRUNISA-2003-03.PDF

Coleman, R. \& LaPlace, L. 2002. E-learning implementation. [Online]. Available WWW: www.rgsinc.com/publications/pdf/ white_papers/elearning.pdf

Geisman, J. 2001. If you build it they will come. Overcoming human obstacles to e-learning. [Online]. Available WWW: www.learningcircuits.org/2001/mar2001/elearn.html

Gold, M. 2003. Enterprise e-learning. [Online]. Available WWW: http://www.learningcircuits.org/2003/apr2003/gold.htm

Grant, R. \& Danzinger, J.N. 2003. Corporate e-learning - exploring implementation and outcomes. [Online]. Available WWW: www.crito.uci.edu/consortium/ 0306mtg/GrantDanziger.pdf

Hollis, E. 2003. JC Penney - fashioning workforce development. [Online]. Available WWW: http://www.clomedia.com/content/templates/clo_casestudies.asp?articleid=103\&zoneid=10

Rosenberg, M.J. 2001. E-learning strategies for delivering knowledge in the digital age. New York: McGraw-Hill.

Sevilla, C. and Wells, T. 2000. E-learning can succeed only with a new mindset. [Online.] Available WWW: www.luminguild.com/elearningcansucceed.htm

Sosbe, T. 2003. Pat Crull: Toys ' $R$ ' Us takes learning seriously. [Online]. Available WWW: http://www.clomedia.com/content/templates/clo_cloprofile.asp?articleid=215\&zoneid=2

Steinbrecher, S. 2003. Successful e-learning implementation in the non-profit organization from input to action. [Online]. Available WWW:

http://www.associationmagazine.com/Client/CSAE/AM.nsf/Articles/

BF722FC4AE65336685256D2000654BE7?OpenDocument

Sweeney, N. 2001. How to be an e-learner. [Online]. Available WWW: http://www.learningcircuits.org/2001/may2001/elearn.html

Weggen, C.C. 2000. E-learning portals, who needs them? [Online]. Available WWW: http://www.learningcircuits.org/sep2000/weggen.html

\section{Disclaimer}

Articles published in SAJIM are the opinions of the authors and do not necessarily reflect the opinion of the Editor, Board, Publisher, Webmaster or the Rand Afrikaans University. The user hereby waives any claim he/she/they may have or acquire against the publisher, its suppliers, licensees and sub licensees and indemnifies all said persons from any claims, lawsuits, proceedings, costs, special, incidental, consequential or indirect damages, including damages for loss of profits, loss of business or downtime arising out of or relating to the user's use of the Website. 
ISSN 1560-683X

Published by InterWord Communications for Department of Information Studies, Rand Afrikaans University 